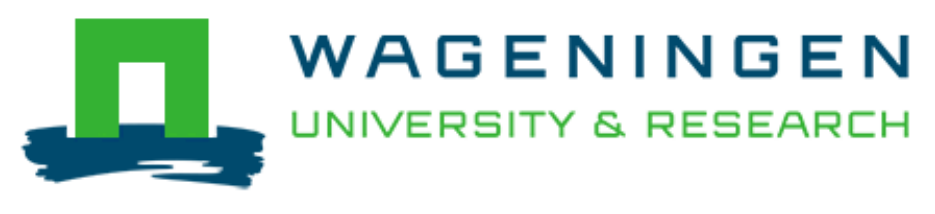

\author{
Renewable energy in Russia: The take off in solid bioenergy? \\ Pristupa, A. O., \& Mol, A. P. J.
}

This is a "Post-Print" accepted manuscript, which has been published in "Renewable and Sustainable Energy Reviews"

This version is distributed under a non-commercial no derivatives Creative Commons (c) (1) $\otimes(\theta$

(CC-BY-NC-ND) user license, which permits use, distribution, and reproduction in any medium, provided the original work is properly cited and not used for commercial purposes. Further, the restriction applies that if you remix, transform, or build upon the material, you may not distribute the modified material.

Please cite this publication as follows:

Pristupa, A. O., \& Mol, A. P. J. (2015). Renewable energy in Russia: The take off in solid bioenergy? Renewable and Sustainable Energy Reviews, 50, 315-324.

https://doi.org/10.1016/j.rser.2015.04.183 


\title{
Renewable energy in Russia: the take off in solid bioenergy?
}

\author{
Alexey O. Pristupa ${ }^{1}$ and Arthur P.J. Mol \\ Environmental Policy Group, Wageningen University, P.O. Box 8130, 6700 EW Wageningen, \\ The Netherlands
}

\begin{abstract}
Triggered by debates on climate change and energy security, renewable energy sources are presently high on the political agenda in many countries. In this regard Russia seems to stand aside worldwide developments. Until recently Russia's enormous potential in renewable energy sources remained poorly utilized. However, Russia's formal commitment to the global climate change regime, its new Energy Strategy 2030, and an increase in wood pellet production suggest a discontinuity. This paper investigates and explains the (limited) progress in the solid bioenergy sector in Northwest Russia. With little Russian experience in this sector, poor technological knowledge on renewables, and inadequate domestic market structures, the development of a domestic solid bioenergy sector is far from easy. Hence, Northwest Russian wood pellet developments cannot be traced back to new federal policies, only partly to local demand and stimulation, and significantly to foreign drivers. Major EU demand for wood pellets and intensified collaboration with foreign companies and organisations leading in the field of solid bioenergy research, technology and trade have triggered these developments. But it is a long way before Russia will be released from its fossil fuel addiction, as repeatedly promised by governmental officials.
\end{abstract}

Keywords: Russia; renewable energy; wood pellets; solid biomass; policies

\section{Introduction}

Climate change and energy security have been the most widely discussed problems in the recent years on sustainability agendas. In these debates the development of renewable energy sources is often seen as an adequate response, as it secures energy provisioning with less impact on the environment. While countries all over the world face the challenge of and developed policy for increasing the share of renewable energy in their national economies, until recently Russia proved to be one of the few exceptions. With large fossil fuel reserves ${ }^{2}$, major state companies pursuing high interests in capitalizing on a fossil fuel economy and export, a state-dominated economy and technological innovation system, little room seems to

\footnotetext{
${ }^{1}$ Corresponding author. Tel: +31317 485849; fax: +31 317483990 .

Email addresses: alexey.pristupa@wur.nl, alexey.pristupa@gmail.com

${ }^{2}$ Russian authorities estimate recoverable oil and natural gas reserves at 17,8 billion tonnes and 48,8 trillion $\mathrm{m}^{3}$ respectively, enough for several decades at current production rates [1]. New hydrocarbons discoveries in the Russian Arctic will arguably drive these estimations even higher.
} 
exist for developing a renewable energy sector. Hence, the percentage of combined geothermal, solar energy, wind energy, bioenergy and biofuels remains at around $1 \%$ of total energy generation; only hydropower has developed more significantly, and is responsible for almost $2 \%$ of total primary energy supply in Russia [2] (Fig. 1). According to Russian national policy-makers among the renewables (solid) biomass plays only a marginal role [3]. Out of the 156 existing major renewable power facilities 6 are using biomass, 3 use biogas, 2 use associated gas from coalmining, and there are 2 tidal power plants, 8 wind power plants, 134 hydropower plants and 1 solar power plant.

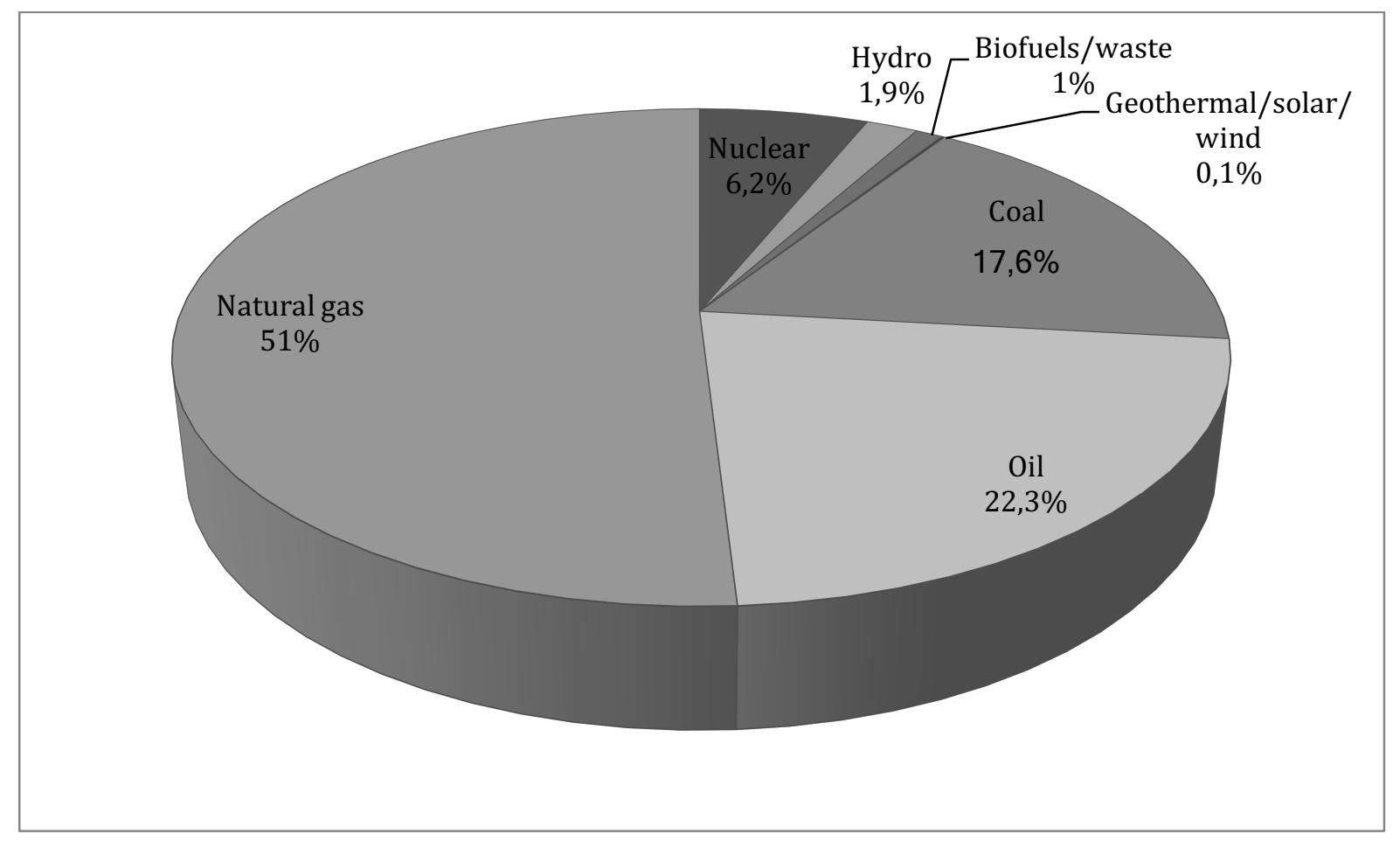

Fig. 1. Share of total primary energy supply in Russia (2012) [2].

Russia's Energy Strategy till 2030 [4] is sometimes regarded as a turning point in Russian energy policy, as it for the first time defined quantitative targets for electricity generation from renewable energy. Moreover, the Strategy prioritizes the development of an innovative economy through advances in innovative technologies in energy efficiency and non-carbon energy sources, with a gradually reducing role of the state. Arguably, the region and sector where developments in non-hydro renewables have progressed most strongly lately in Russia is solid biofuels (especially wood pellets) in Northwest Russia. For two decades, this region has been involved in solid bioenergy production, domestic use and export to bordering states, mainly EU countries such as Finland and Sweden. In analysing this development of solid bioenergy in Northwest Russia we aim to better understand the main drivers and favourable conditions for further expansion of the solid bioenergy sector in Northwest Russia and green innovation in the Russian energy sector. 
Data for this case study have been collected through literature review, analysis of local, national and regional policy documents, analysis of statistical data on renewable energy in Northwest Russia, and through 18 in-depth interviews with different stakeholders in the Northwest Russian bioenergy sector (regional organisations, financial institutions, Russian governmental agencies, companies, research institutions, and environmental NGOs). The next section introduces developments in Russia's solid bioenergy sector, with special focus on Northwest Russia. Subsequently, we analyse to what extent federal policies, domestic developments in Northwest Russia, and foreign involvement and linkages can explain the modest take off of solid bioenergy in Russia. The final section draws some conclusions.

\section{Solid bioenergy production in (Northwest) Russia}

\section{Forest and wood energy}

Northwest Russia, officially named the Northwestern Federal District ${ }^{3}$, is the most European part of Russia, sharing a border of more than $2000 \mathrm{~km}$ with 7 European countries. The District includes eleven administrative areas: the Republics of Karelia and Komi, Nenets Autonomous Okrug (under administrative jurisdiction of Arkhangelsk region), the Arkhangelsk, Kaliningrad, Leningrad, Murmansk, Novgorod, Pskov and Vologda regions, and the regional capital of Saint Petersburg (Fig. 2). With nearly 1.7 million $\mathrm{km}^{2}$ and only 13.6 million citizens (5 million living in St. Petersburg) the District is sparsely populated [5].

Forests account for around 52.5\% (88.5 million ha) of land in Northwest Russia [7], an area almost equal to France and the United Kingdom together. Mature and over mature forests constitute some 6 billion $\mathrm{m}^{3}$ of the total 10 billion $\mathrm{m}^{3}$ growing stock [8]. Most of the forest resources are found in the regions Vologda and Arkhangelsk, and Republics of Karelia and Komi [7]. Main tree species used in the forest industry comprise spruce, pine, birch and aspen, with the former two prevailing in the northern boreal forest [9].

Forestry and pulp and paper industries are among the most important industries in the Russian Northwest. On a national scale some $61 \%$ of pulp and paper, $37 \%$ of plywood, around $33 \%$ of industrial roundwood, and $28 \%$ of sawn timber was produced in the region in 2010 [10]. However, the industrial potential is not fully used, as only 50 million $\mathrm{m}^{3}$ of the 124 million $\mathrm{m}^{3}$ annual allowable cut was harvested in 2010 [11]. The actual harvest comprised 40.2 million $\mathrm{m}^{3}$ from mature stands $(80.4 \%), 5.1$ million $\mathrm{m}^{3}$ from thinnings $(10.2 \%)$ and 4.7 million $\mathrm{m}^{3}$ from other felling $(9.4 \%)$, pointing at extensive forest management practices [10]. ${ }^{4}$

\footnotetext{
${ }^{3}$ In 2000 (Presidential Decree No. 849) seven (now nine) federal districts were created, each headed by a Representative of the President of the Russian Federation. These Representatives oversee federal law compliance in the administrative regions of the districts.

${ }^{4}$ For instance, in intensive forestry management practices in Sweden thinning account for $30 \%$ of the total annual cut [12].
} 


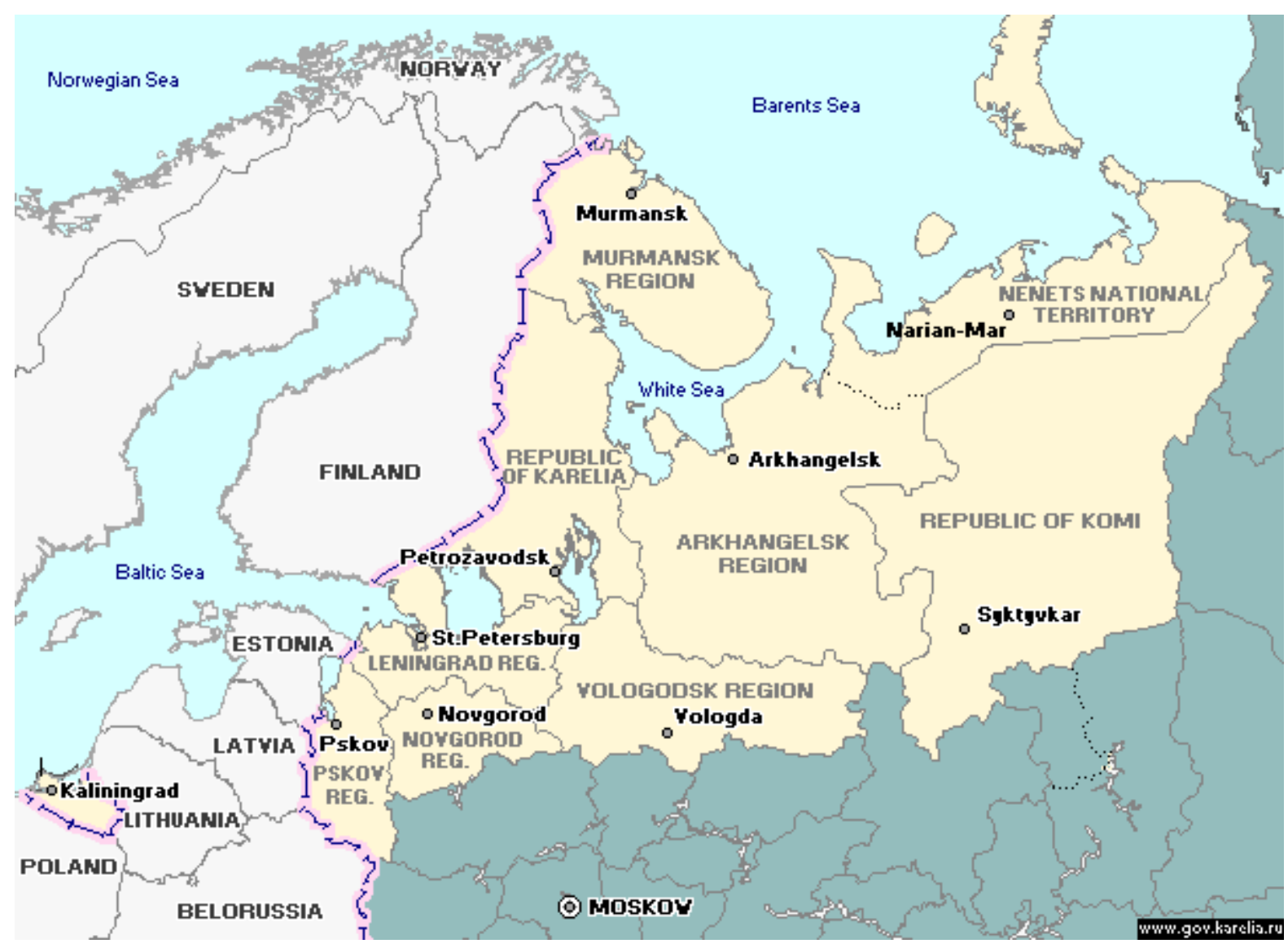

Fig. 2. Map of the Russian Northwest region [6].

\section{Bioenergy production}

In Russia the development of the wood bioenergy sector began in the early 2000s against the background of an improving national economic situation and a rapid growth of demand for green energy around the world. Wood pellets production has received particular attention in Northwest Russia and later also in other regions with rich forest resources and a developed wood industry. However, large availability of forest resources, a relatively developed logistical infrastructure and proximity to the EU enabled Northwest Russia to become a pioneer in the wood pellet business [13].

Wood pellets are solid biofuels with standard quality: low moisture content, high energy density and homogenous size and shape [14]. Pellets are made by compressing wood particles into small granules of 6-10 mm diameter size. Softwood (coniferous trees such as spruce, pine, larch) or hardwood (birch, aspen, alder) can be used for production of wood pellets [15]. Logs as well as low quality timber, sawdust and waste from logging and wood processing industries can be used for pelleting. Wood pellets represent a more efficient form of energy than regular firewood and are generally used for heating and electricity generation.

Small-scale pellet production in Northwest Russia started in 2001 at LLC Biofuel plant in Leningrad region, close to Saint Petersburg. This experimental facility did not produce large volumes of pellets, but provided important evidence and experiences for manufactures. Shortly after 2001 another 2-3 pellet plants started operations in Leningrad region [16]. In 
2003 6-7 enterprises manufactured wood pellets and the Russian Biofuel Association was created to actively promote and support production and export of solid biofuel, as well as cooperation with foreign investors and equipment suppliers. In the following years the number of producers, production volumes and export volumes of wood pellets continued to grow (Fig. 3). ${ }^{5}$ Most of Russian wood pellet production is concentrated in the Northwest Russia, although production for foreign markets also appeared in Siberia and Far East.

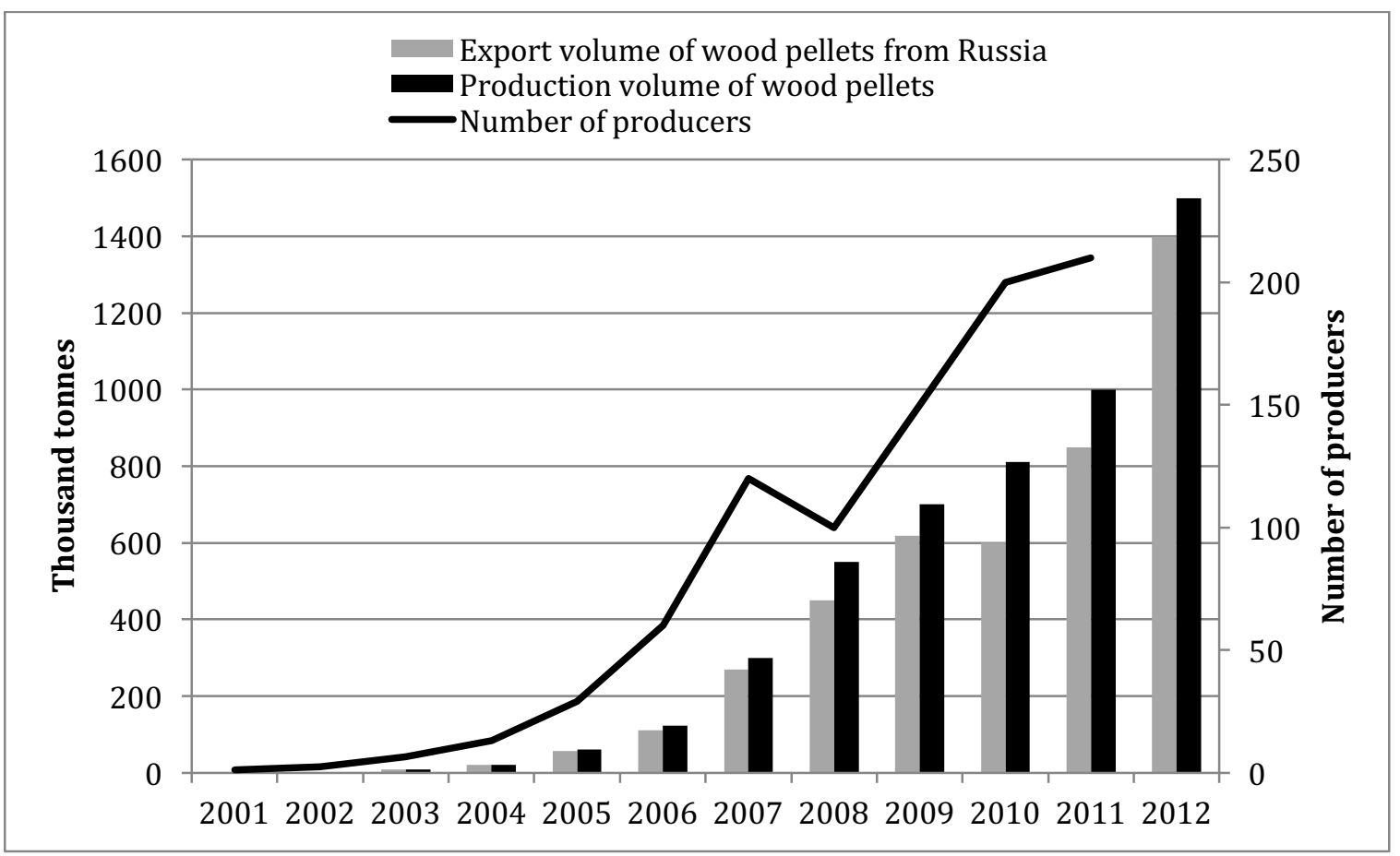

Fig. 3. Developments in wood pellets producers (right axis), production and exports from Russia (compiled by the authors from [16-22]).

By the mid-2000s extensive networks were constructed and maintained through a specialised magazine, and numerous conferences and seminars on wood pellets production technology and market developments. In 2007 several pioneering small-scale wood pellets manufacturers shut down due to increased competition for raw materials between wood pellets manufactures and pulp and paper industry, enhancing large-scale production and increasing capital investments $[24,25]$. Production capacities of $60,000-80,000$ tonnes per year per plant became common, and production technology and business management professionalized.

Currently several large woodworking and forestry companies dominate Russian production and export of wood pellets. The five largest companies are responsible for about half of all export of wood pellets in 2013 (Table 1). Northwest Russia accounted for $87 \%$ of national wood pellet production in 2012, although some large companies emerged in Siberia and Far East of Russia (e.g. DoK "Enisey" and "Arkaim”) [22]. The major export markets for Russian pellets are located in Denmark, Sweden and Finland, new major markets have emerged in

\footnotetext{
${ }^{5}$ Different sources present varying information on the wood pellets statistics, e.g. [13,16,23], but all sources and informants report a general upward trend.
} 
South Korea [26] and smaller volumes are being exported to nearly 20 other European countries.

\section{Table 1}

Capacity and export estimations (2013) of the five largest pellet producing companies in Russia (compiled by the authors from [19,27,28] and personal communications).

\begin{tabular}{|c|c|c|c|}
\hline Company & $\begin{array}{l}\text { Export volume, } \\
\text { (thousand tonnes) }\end{array}$ & $\begin{array}{c}\text { Installed production } \\
\text { capacity (thousand tonnes) }\end{array}$ & Region \\
\hline $\begin{array}{l}\text { Vyborg Forest } \\
\text { Corporation }\end{array}$ & 263 & 1000 & $\begin{array}{l}\text { Leningrad, } \\
\text { Northwest Russia }\end{array}$ \\
\hline Arkaim & 119 & 240 & $\begin{array}{l}\text { Khabarovsk, Far } \\
\text { East of Russia }\end{array}$ \\
\hline DoK Enisey & 108 & 130 & $\begin{array}{l}\text { Krasnoyarsk, } \\
\text { Eastern Siberia }\end{array}$ \\
\hline Lesozavod-25 & 74 & 110 & $\begin{array}{l}\text { Arkhangelsk, } \\
\text { Northwest Russia }\end{array}$ \\
\hline Novoyeniseyskiy LPH & 58 & 80 & $\begin{array}{l}\text { Krasnoyarsk, } \\
\text { Eastern Siberia }\end{array}$ \\
\hline
\end{tabular}

\section{Federal neglect of bioenergy}

In Russia the importance of renewable energy sources, among which bioenergy, was for the first time mentioned by the Ministry of Energy in 1994 through the concept of small and alternative energy development. For the first time locally available fuels were assessed and estimations were provided for all types of renewable energy sources [29]. Subsequently, in the 1990s and early 2000s renewable energy returned several times on the political agenda, but was never successfully taken up in any national energy policy. Some policy initiatives, such as the 1999 draft law "On the State Policy in the Sphere of Unconventional Renewable Energy Sources", were turned down; other initiatives lacked priority and remained underfinanced, such as the 2001 "Renewable Energy in Northern Territories" plan as part of the Federal programme for Energy Efficient Economy 2002-2005. The 2003 Russian Energy Strategy systematically addressed the long-term development of the energy sector till 2020 , but only mentioned peat and firewood as most promising local renewable energy sources and lacked a comprehensive, coherent and innovative approach towards renewable energy sources. Clearly, developing renewable energy sources did not belong to the national economic and political priorities of that time [30].

Although no longer ignored, efforts to operationalize and implement a strategy to develop renewables also stagnated after the mid 2000s. For example, the 2007 amendment of the Federal Law No. 35-FZ “On electric power industry”, aiming to create a financial instrument ${ }^{6}$ to support enterprises generating green energy, has not been translated into practice; and other regulations have been severely delayed [31]. Frequent - almost annual - changes of internal governmental structures [32] and leading responsible officials in governmental institutions,

\footnotetext{
${ }^{6}$ See Boute [37] for more details on Russian support schemes for renewable energy.
} 
including the Ministry of Energy, have contributed to extremely slow, weak and fragmented political processes in this field. Currently, the Russian Energy Agency, established in 2009 under the Ministry of Energy, is entrusted with practical implementation of the state policy in monitoring, training, coordination and promotion of energy efficiency, renewable energy and innovation in the energy industry. But coordination of the development of bioenergy is performed through an interdepartmental working group, consisting of representatives of the Ministry of Energy, Ministry of Agriculture, Ministry of Economic Development and Russian Agricultural Academy.

Some signs of progress came in 2009 with the launching of the Federal Law "On Energy Saving and Increasing Energy Efficiency" and the Energy Strategy up to 2030. Governmental policy addressed renewables through the broader agenda of energy efficiency. The 2009 Decree on "Main Directions for the State Policy on Energy Efficiency of the Electricity Sector on the Basis of Renewable Energy Sources Until 2020" contains quantitative targets for electricity generation from renewable energy, namely $1.5 \%$ and $4.5 \%$ in 2010 and 2020 respectively, and an outlook towards $8 \%$ in 2030. The target of $1.5 \%$ in 2010 has failed and it is unlikely that the other upcoming targets will be met [33]. Recently, in the State Programme on "Energy Efficiency and Energy Development" for the period 2013-2020 the Russian government has decreased the 2020 objective for electricity production from renewable energy sources to $2.5 \%$ [34]. Renewable energy targets in Russia are rather flexible and can change quickly over time.

Development of bioenergy is addressed in several recently developed policy acts. For example, the 2013 Forestry Policy till 2030 mentions bioenergy and wood pelleting among the measures to improve the efficiency and profitability of the forest sector [35]. Additionally, the 2012 "Integrated Programme of Biotechnology Development in the Russian Federation for the period up to 2020" targets a broad development of various fields of biotechnology, among which bioenergy [36]. Both, however, do not go beyond general provisions and statements, and lack concrete (action) plans, sufficient budgets, and instruments. Arguably the most concrete national policy on stimulating bioenergy is related to technological innovation. The Russian government has created "technology platforms", where representatives from public, private, scientific and civil society institutions collaborate on innovation. Of the first 25 approved Russian technology platforms two relate to bioenergy: the Bioenergy Platform and the Russian Forest Technology Platform (RFTP) [38]. Critical voices point out, however, that technology platforms lack financial resources as well as formal instruments. Activities are often carried out on a project and ad hoc basis rather than representing a coherent long-term (technology) development strategy (personal communications).

Hence, overall the Federal government has achieved little to develop the renewable energy sector in general and the bioenergy sector in particular.

\section{Domestic bioenergy market development: Northwest Russia}

The enormous fossil fuel resources in Russia are unevenly spread. Most of the currently operating oil and gas fields are located in the Western Siberian region of Tyumen, in its Yamalo-Nenets and Khanty-Mansi Autonomous Okrugs [39]. The majority of Russian 
regions, less fortunate in fossil fuels reserves than Siberia, have to procure gas and oil for their regional electricity and heat generation. The federal level generally overrules regions in many respects, particularly with regard to energy policy. Because of the priority given to the development of fossil fuels, federal energy subsidies increase regional dependency while domestic fossil fuel price volatility further aggravates regional energy security. Thus, in contrast to the federal level, regions reveal more enthusiasm towards development of renewable energy, and in the case of Northwest Russia solid bioenergy appears to be most promising.

\subsection{Rationales for a domestic bioenergy market}

There are major potentials and drivers towards a larger use of solid bioenergy. In Northwest Russia gas, oil and coal represent around $80 \%$ of energy consumed and is to a large extent imported from other Districts or transported from the oil-rich Nenets Autonomous Okrug and Republic of Komi [40]. This vulnerability encouraged several Northwest Russian regions (e.g. Karelia, Arkhangelsk, Novgorod, Vologda, and Leningrad regions) to initiate regional forest bioenergy programmes. The urgent need for reconstructing and modernising the central heating system further stimulates bioenergy in Northwest Russia. Ageing of heating infrastructure has reached extreme levels: $65-70 \%$ of district heating fixed assets are obsolete [4], $80 \%$ of the boilers are over 30 years old and $20 \%$ are over 50 years old; and more than half of the 200,000 kilometer fossil fuel pipeline network is beyond technical life expectancy [41]. This results in high energy losses during production, distribution and consumption, and increasing numbers of failures and accidents (27\% increase between 2006 and 2009) [42].

Besides, conversion of oil and coal boilers to biomass boilers would also reduce greenhouse gas emissions [10].

The forest industry has major potentials, both as consumer of biofuels and supplier of biomass to power generation companies and local utilities. Logging residues (e.g. tops of trees, branches and cut-offs of tree stems), low quality round wood from felling and thinning, and by-products of wood and pulp industries (e.g. sawdust, bark and chips) represent potential "energy wood" that could be used for energy generation to (partially) substitute fossil fuels in the energy balance. More than $60 \%$ of potential solid bioenergy in Northwest Russia comes from logging 'residues' and the rest from wood processing and pulp industry [43]. Based on current 50 million $\mathrm{m}^{3}$ actual cut and actual mechanical wood processing potential bioenergy production in Russian Northwest from these three 'residue sources' is estimated at $61.8 \mathrm{TWh}$. Full utilisation of the annual allowable cut (some 124 million $\mathrm{m}^{3}$ ) and thinning as well as increased capacity for mechanical wood processing can deliver 207.8 TWh [10]. This is about double the total amount of electrical energy produced in Northwest Russia in 2013 (101 TWh) [44].

But the current share of biomass, together with other renewables, in energy consumption of Northwest Russia is only $2 \%$ [45]. Poor use of locally available wood resources and poor utilisation of residues and wastes from the wood processing industry contribute to this. While more than half of the country's pulp and paper is produced in Northwest Russia, the timber, 
pulp and paper industry meets only some $20-30 \%$ of its own energy needs through solid biofuels, compared to $52 \%$ in Europe [46].

\subsection{Development of domestic market}

A domestic wood energy market has developed rather recently in Russia and is still marginal compared to the European one. Domestic use of wood pellets has grown from around 5\% in 2007 to a fluctuating level of $10-15 \%$ in 2012 [13,21]. Currently there are about 200 wood pellet mills active in Russia, varying from few large producers with plant capacities of more than 100,000 tonnes per year to many small enterprises with small wood pellets production capacities. A specialisation exists among the companies, with the large producers oriented towards exports to the European market and small manufacturers covering both foreign and domestic markets (see Box 1). Availability of own feedstock as well as fluctuating European market prices and demand for wood pellets stimulate companies to turn to local markets and to become self-sufficient in company energy provisioning [20]. It is estimated that with doubling of wood biomass for energy use by 2030 , from 32 million $\mathrm{m}^{3}$ to 75 million $\mathrm{m}^{3}$, the national market will be more important than the export market for wood pellets [47].

Renewal of district heating systems has also boosted the development of the local wood pellet market. Conversion of municipal boilers to biomass provides pellet producers a stable demand for their products. The Republic of Karelia illustrates the potential of bioenergy by successfully initiating in 2007 a regional programme "Active use of local energy resources for 2007-2010" to use locally available biomass in developing the heating sector. Among the 429 municipal boilers, 132 were converted to the use of fuelwood (i.e. wood, sawdust) and 17 run on wood chips. Among the 181 boilers that run on coal, 54 are co-fired with wood in spring and autumn. Consequently, wood energy accounts now for $18 \%$ of the Republic's municipal heat supply, which is significantly more than in other parts of the Russian Northwest and elsewhere in Russia [20].

In addition, wood pellets are becoming increasingly popular with private owners of small- and medium-sized heating stations as well as private householders, especially in areas with high forest cover and lack of or expensive mineral energy sources [47]. In such areas wood pellets can be cheaper than gas, which improves competitiveness [48]. Pellet producers lobby local administrations to switch boilers to wood pellets and negotiate with large supermarkets to sell energy wood for small private consumers [49]. Larger pellet manufacturers, such as Novotop in Moscow, even open warehouses in big cities for selling mainly energy wood directly to local residents [15].

While large manufacturers are primarily responsible for the growth of wood pellet production, small plants have advanced in wood briquettes. Wood briquette production in Russia in 2012 has reached 300,000 tonnes a year, with almost half of it sold on the domestic market [22]. Small businesses seem to gradually leave the pellet manufacturing sector and switch to briquette production [21]. 


\section{Box 1. Domestic market: Sawmill-25}

Lesozavod-25 (Sawmill-25), based in Arkhangelsk and part of the "Titan" group, is the largest woodworking enterprise in Northwest Russia. It processes about $800,000 \mathrm{~m}^{3}$ round wood yearly, resulting in significant amounts of wood waste, mainly wood chips, bark and sawdust. Wood chips are sold to pulp and paper industries, bark is used at combined heat and power (CHP) facilities for own consumption, and sawdust $\left(136,000 \mathrm{~m}^{3}\right)$ is used for wood pellet production. Using round wood for wood pellet production is economically not feasible at Sawmill-25. Sawmill-25 has used Joint Implementation financing twice. Firstly, the CHP plant was installed that increased the amount and efficiency of bark and wood waste use as a fuel for generating heat and electrical power. The total emission reduction of this project accounted for 215,000 tonnes of $\mathrm{CO}_{2} \mathrm{eq}$ [50]. Secondly, the wood pellet facility was financed through Joint Implementation due to cut down of methane emissions equal to some 100,000 tonnes of $\mathrm{CO}_{2}$ eq [51].

The wood pellet facility was launched in 2008 and operates now three pellet production lines, producing annually 50,000 tonnes of pellets (personal communications). While 30,000 tonnes are exported to the Netherlands, Belgium and Denmark, local pellet use is expanding through cooperation between Arkhangelsk city municipality and the sawmill. Sawmill-25 constructed, owns and maintains 5 pellet boilers with a capacity of $1.5 \mathrm{MW}$ to $4.5 \mathrm{MW}$. Sawmill-25 sells heat to the city residents for which $30-40 \%$ of produced pellets are used [52]. Development of the domestic market allows Sawmill-25 to diversify sales and safeguard stable pellet production, regardless of the volatile (European) pellet price and demand.

The forest plots leased by Sawmill-25 are all FSC certified, but part of the purchased round wood (around 60\%) does not have FSC certification. The representative of Sawmill-25 did not witness yet FSC requirements for pellet exports to Europe and domestically forest certification for pellet production is also not required.

\subsection{Obstacles of domestic bioenergy use}

Despite these rational reasons and potentials to increase the use of biomass in Northwest Russian regions, major obstacles remain. Regional initiatives to improve energy efficiency and introduce biomass for energy production are carried out under the framework of the 2010 State Programme for energy saving and energy efficiency for the period up to 2020 [53]. The programme co-finances regional measures on the basis of signed agreements. The total estimated funding till 2020, some $€ 237$ billion, is shared between federal budgets, regional budgets and "extrabudgetary sources" (private investors) in the proportion of $0.7 \%, 6.6 \%$ and 92.7\%, respectively. "Extrabudgetary sources", the major share of investments, represent the weakness of the programme. The Russian Audit Chamber reported that the Programme lacked $40 \%$ of the planned funding ( $€ 15$ billion) for 2012 , mainly because of insufficient contribution from "extrabudgetary sources", such as energy companies and other private entities [54] (see also Box 1 and 2).

The complex and non-transparent system of financing municipal heating in the Russian Federation poses a major obstacle to the conversion to local energy sources $[55,56]$. Stakeholders involved in modernisation of municipal heating often have conflicting interests and the private investment climate is uninviting [20]. Moreover, by the end of 2012 only $28 \%$ of all regions had adopted regional legislation on energy saving and energy efficiency, as 
stipulated by federal law. Hence, the modernisation and greening of the energy system proceeds very slowly and half-a-century old fossil-fuel based energy generation facilities remain common ${ }^{7}$ [54].

\section{Box 2. Export market: Vyborg Forest Corporation}

Vyborgskaya Cellulose is one of the oldest and largest pulp and paper enterprises in Russian Northwest. After privatisation in the early 1990s, in 2010 Vyborgskaya Cellulose (renamed in 2011 into Vyborg Forest Corporation) revealed plans for the construction of the world's largest wood pellet plant with an annual production capacity of 1 million tonnes, located on the Baltic Sea coast close to the border with Finland. Vyborg Forest Corporation is a pellet producer fully oriented towards export to Europe.

The French subsidiary of Russian VTB bank together with Texel Capital Ltd has financed the pellet plant, taking into account an expected payback time of 7 years and with the Swedish trader Ekman \& Co as exclusive sales agency for selling wood pellets on European markets [87]. Foreign technology was purchased, including two debarking lines, four belt dryers, 16 hammer mills and 36 presses (personal communication).

Resource availability for such a giant pellet plant is crucial. An installed capacity of 1 million tonnes requires about 2.5 million $\mathrm{m}^{3}$ of low grade round wood as raw material. The company secured raw material delivery from Leningrad, Pskov and other regions, through leasing forest plots for 49 years according to the Forest Code, and from forest auctions in other Russian regions (personal communications). The company focuses on FSC certification of leased forest plots as well as purchasing FSC certified wood from enterprises (personal communications), guaranteeing access to European markets. Even though the close location to European markets and construction of a port terminal for pellet shipment provide the company a competitive advantage [18], the company continuously operates below installed capacity (at 300,000 tonnes per year) [28]. Round wood harvesting and transport expenses add up to about $€ 80$ per tonne, while average wood pellet prices fluctuate around $€ 100$ per tonne [15]. In 2013 the company had a debt of $€ 10$ million [88].

\section{Foreign bioenergy markets}

The trade volume of wood pallets has increased rapidly between 2000 and 2010, from 8.5 PJ to $120 \mathrm{PJ}$ [57]. The EU is the major consuming market for wood pallets, with a trade volume between EU and non-EU countries of $45 \mathrm{PJ}$ in 2010, comparable in size to biodiesel and bioethanol trade [27]. Russia is the third largest wood pellet exporter to the EU $(675,000$ ton in 2012) after Canada (1,220,000 ton) and the USA (1,955,000 ton) [58]. The main driver for European wood pellet demand is the ambitious EU strategy for the reduction of greenhouse gases (GHG) and the increased use of renewable energy embodied in so-called " $20-20-20$ targets" or Climate and Energy Package: a mandatory target of $20 \%$ renewable energy in final energy consumption by 2020, as well as a minimum of $10 \%$ for biofuels [59]. In 2012 there were approximately 500 pellet plants operational across Europe, producing around 10.6 Mtons of pellets which equals around $50 \%$ of global production [58]. The European Union

\footnotetext{
${ }^{7}$ As an illustration, generators at Omsk and Saransk CHPP are in operation for 50 years, twice as much as their service lifetime. Energy losses in energy networks have reached $10-12 \%$ by 2012 , while these were estimated at $2 \%$ at the beginning of the 1990 s [54].
} 
consumes $85 \%$ of global wood pallet demands and the gap between production and consumption in the EU (2.5 Mtons in 2010) is still growing [27].

The proposal of the EU Commission to raise the EU renewable energy targets to $27 \%$ by 2030 [60] is expected to increase European demand for pellets in the coming decades. While presently the world market experiences no shortage of energy from wood, doubling the wood supply to meet renewable energy targets would be a significant challenge and would involve substantial environmental, financial and institutional costs. In this light Northwest Russia, with its vast forest resources and closeness to the EU, offers an attractive opportunity for stable wood pellet imports [61].

\subsection{Cross-border cooperation for the development of bioenergy}

Northwest Russia has historically played an important role in relations between Russia and Europe. After the collapse of the Soviet Union Northwest Russia became increasingly engaged in cross-border cooperation networks. Early cooperation initiatives in the 1990s were framed around the development of civil society, fostering democracy and stimulating the transition to a market economy. Later economic cooperation started to prevail. Many peripheral regions of Northwest Russia have developed different forms of cross-border cooperation, varying from ad hoc collaborative activities to more structured and institutionalized cross-border integration, such as Euro-regions. Cooperation on sustainable energy and biomass was always central in cross border cooperation.

The 1990s were characterised by rapid evolvement of transboundary energy cooperation between Northwest Russia and neighbouring countries. The first years of collaboration resembled an euphoria associated with far-reaching aspirations of the involved actors for seemingly unlimited opportunities and bright perspectives of cooperation [62]. The transformation of the Northwest Russian energy system, however, did not happen at the desired speed and economic cooperation had mixed successes. Nevertheless established transboundary networks paved the path for further regional collaboration. Building trust and recognising cultural, institutional and legal differences became an important part of early cooperation networks [63]. The starting bilateral energy cooperation later engaged regional and multilateral organisations. In addition, aid cooperation in the early 1990s was increasingly shifting towards mutually beneficial collaboration and market relations between Russian and Nordic actors in the 2000s.

\section{Cooperation with Nordic countries}

Sweden was among the first European countries after 1990 to set up energy collaboration with Northwest Russia and the Baltic region through the framework of Environmentally Adapted Energy Systems (EAES) programme. The EAES programme was launched in 1993 as part of the Pilot Phase of Activities Implemented Jointly (JI) within the UN Framework Convention on Climate Change. It primarily focused on energy efficiency improvements and increasing 
use of renewable energy sources in the Baltic Sea region (Estonia, Latvia, Lithuania, Poland, Northwest Russia) [64]. ${ }^{8}$

The main activities in EAES addressed emission reduction potential from oil or coal-fired energy production plants through conversion to the use of wood biofuels, reduction of heat losses in district heating systems, and improving energy efficiency in buildings [65]. Activities were funded via loans from the Swedish National Energy Administration to municipalities or municipal heating companies for the period of 10 years. It was a "learningby-doing" experience in transfer of robust technology, market transformation and capacity building [66]. ${ }^{9}$

Disappointing examples, however, were not rare. The conversion of a district heating plant to wood biomass in the village Derevyannoe in the Republic of Karelia took two years of obtaining permission and persuading all parties of the feasibility and the benefits of a biomass-powered heating system. After final start-up in 2000, the company never managed to become profitable and went bankrupt in 2007. But the successes and failures did provide Swedish companies knowledge and experience of working in Russia, and gave Russian actors new technological insights and skills to function under market conditions. A broad network of authorities, universities, energy institutes, municipalities, and energy companies was created with experiences in knowledge and best practices collaboration. Likewise, Denmark, Finland and Norway built cross-border networks on modernization of the energy system, energy efficiency and renewables [69-73]. More recently cooperation agreements in energy efficiency and renewable energy were signed between Russian agencies and some European states (Netherlands, France, Italy, the United Kingdom, Portugal, Slovakia, Ireland and Iceland).

\section{Involvement of regional and multilateral actors}

Towards the change of the Millennium Nordic countries increasingly consolidated their energy cooperation with Russia through programmes of regional and multilateral organisations. Northwest Russia remained a primary focus for cross-border cooperation. ${ }^{10}$

By 2002 the EAES programme transformed into the Swedish International Climate Investment Programme (SICIP). The SICIP programme operated in close cooperation with the Baltic Sea Region Energy Cooperation (BASREC), which was initiated in 1998 by the energy ministers of the Council of the Baltic Sea States CBSS. ${ }^{11}$ CBSS pursued cooperation in the energy sector as it was seen as key to political stability, security of energy supply, economic growth and sustainable development in the Baltic Sea region. In addition, the Barents Euro-Arctic Council (BEAC) initiated in 1998 a Joint Working Group on Energy (JEWG), aimed at promoting cooperation between energy experts, authorities, and investors,

\footnotetext{
${ }^{8}$ The Russian-Swedish Bioenergy Information and Training Centre (BioCenter) was established in 2002 as a spinoff of the EAES programme [67].

${ }^{9}$ Some $€ 4$ million was invested in Russia between 1993 and 2000, which resulted in saving of 78,000 MWh of energy and reduction of 23,000 tonnes of $\mathrm{CO}_{2}$ eq annually [68].

${ }^{10}$ Only the most important networks are mentioned here. For a more elaborate list of active networks and actors see Lausala and Valkonen [74] and State of the Region Report by Baltic Development Forum [75].

${ }^{11} \mathrm{CBSS}$ is an intergovernmental organization of five Nordic countries, three Baltic countries, Germany, Poland, Russia and the European Commission.
} 
which facilitated renewable energy and energy efficiency projects in the Barents region [74]. While Russia did hardly put renewable energy on the agenda, through these regional organisations the other member countries and the EU affected Northwest Russia's energy agenda.

Financial institutions have also focused on sustainable energy developments in the region. Nordic Environment Finance Corporation (NEFCO), founded in 1990 by the five Nordic countries, has been engaged in a wide variety of projects supporting renewable energy, energy efficiency technologies, and modernization of industrial production facilities in Northwest Russia [76]. The International Finance Corporation (IFC) also contributed to shaping renewable energy in Russia by investing at the end of 2010 more than $€ 120$ million via a fiveyear Russia Renewable Energy Programme. The programme's ambitions are 205 MW of installed renewable generation capacity and reduction of 5 million tonnes of GHG emissions over a 20-year investment lifetime, especially in wind and bioenergy [77]. But three years after the start of the programme IFC observed only limited development, particularly at the federal level. While regional developments could provide an alternative to this federal stalemate, a general regulatory framework appears crucial for attracting renewable energy investments in the regions [78]. The 2012 EU-Russia Renewable Energy Plan (RUSTEC) of IFC aims at enhancing regional cooperation between Russia and bordering Nordic countries in biomass, wind, and hydro energy sector [79], but also here lack of federal support may delay implementation [80]. The United Nations Economic Commission for Europe (UNECE) has supported since 2008 the development of Regional Biomass Action Plans (RBAPs) for the Leningrad region, the Tatarstan region and the Krasnodar region [81].

\subsection{Faced challenges}

The development of pellet export from Russia is associated with a number of challenges. Firstly, early production of wood pellets was characterised by low quality products related to absence of specialised machinery and equipment, lack of production experience, poor transportation technologies and infrastructure, and absence of generally accepted product standards and norms. By the mid-2000s pellet producers had modernised their manufacturing with foreign technologies and investment. In the absence of national standards, producers strive to comply with common European pellet standards, such as DIN and DINplus, since 2010 gradually substituted by the pan-European pellets standard ENplus 14961-2 (which covered $40 \%$ of EU pellets consumed in 2013). Sales, however, are usually based on actual quality of exported pellets (e.g. ash and moisture content, calorific value), especially when batches are made up of pellets from different producers with varying quality [15]. Sustainability standards, such as those of FSC, are increasingly used in Russian pellet production but not often required for exports to the EU (see Box 2). ${ }^{12}$

\footnotetext{
${ }^{12}$ In contrast to liquid biofuels, no sustainability criteria have been implemented by the EU for solid biofuels [27] nor for biogas [82]. The first international private standards for wood pellets for energy production included the Green Gold Label (GGL) and the Laborelec system, both Chain-of-Custody (CoC) standards for product verification. They allow the use of other schemes to comply with sustainability criteria set out in the standard (e.g. FSC, PEFC). Currently a consortium of large pellets buyers have formed an initiative called 'International
} 
Absence of standards and monitoring has also affected the reliability of statistical data. There exists no undisputed data on production and export volumes of pellets, and most data are estimates. While it is generally difficult to determine international trade volumes for biomass due to multiple application of biomass streams [84], tracking trade in wood pellets in Russia until 2012 was further complicated as pellet statistics were aggregated under HS 440130 code, which also included sawdust, shavings, wood waste and scrap. Since 2012 Russia employs a separate code - HTS 440131 - for sawdust and wood waste and scrap in the form of wood pellets [48].

Finally, despite the continuous growth in production volumes, actual pellet production remains significantly below installed production capacities of pellet plants (estimated at 3 million tonnes) [49]. Many pellet plants do not operate up to their full capacity (see Box 2). This is explained by flaws in wood pellet projects design and business plans; lack of feedstock and competition for the feedstock between pellet producers; recovery of pulp and paper industry from economic crises; lack of experience in fine-tuning supply of raw material and exploitation of equipment; problems related to market entry and market conjuncture; and poor transport infrastructure $[16,85,86]$. Malikova [86] argues that $51 \%$ of all pellet projects are an investment failure, $13 \%$ of all projects are regarded commercially successful, and $36 \%$ operate at just acceptable performance levels. Diversification of sales strategy by stimulating domestic demand is often considered a new opportunity for pellet companies, as it may further strengthen the position of Russian wood pellet producers, and may make them less vulnerable from the EU market and price dynamics following EU climate and energy policies.

\section{Conclusions}

Wood biomass, and in particularly wood pellets development, is gaining momentum in Russia. Rapid growth of production volumes, extending production capacities and rising export volumes of wood pellets during the last decade have been accompanied by advancing market structures, creation of new institutions and recent advances in sustainable energy policies. Throughout this decade cooperation has intensified in regional networks. Earlier programmes of Nordic countries and regional organisations aimed at the transformation of the energy sector in Eastern Europe have resulted in neither quick institutional shifts nor rapid transition towards efficient and sustainable energy systems. Nevertheless, these programmes created cross-boundary networks of different stakeholders specialized in energy efficiency measures and renewable energy sources. These networks served as a basis for more successful cooperation projects and joint research activities on sustainable wood biomass in Russian Northwest, as it is the case with the Swedish-Russian "BioCentre" and the Norway-initiated Energy Efficiency Centres. With mounting wood biomass demand from Europe, Russian wood pellet producers have set up stable contacts with European and Russian biomass traders. And the established cooperation structures, knowledge networks and best practices prove vital in the current take off of domestic sustainable energy initiatives.

Wood Pellet Buyers' (IWPB) to streamline their quality and sustainability requirements to facilitate trade within the sector [83]. 
Governmental attempts to stimulate innovation by linking stakeholders from public sector, business and academia, for instance through technology platforms, have had little results up till now. This is also valid for the recently adopted state policies: these rather legitimize existing private initiatives, such as wood pellets production, but do not provide tangible support to further expand renewable energy in general. Moreover, national priority given to development of hydrocarbons on the federal level has discouraged envisaged progress in renewable energy sources. However, policies and programmes on regional and local levels within Russia, have been more instrumental in recognising and advancing the potential of sustainable energy initiatives and the accommodation of new developments in existing economic structures. Regional governments have provided limited policy measures, mainly through subsidies to stimulate new ventures. There is a constantly growing number of compact biomass boilers in residential, municipal, and small industry heating systems that enhances local demand for wood residues, wood pellets and briquettes [57].

Despite the orientation of large wood pellet companies to European exports, domestic market demand for wood pallet has increased as well. Price and demand fluctuations on the European wood pellet market stimulated Russian producers to diversify markets. This resulted in implementation of projects aimed at modernisation of pellet production processes and reduction of fossil fuel consumption. Additionally, regional energy security concerns have raised appreciation of locally available energy sources. Regions have reacted with varying success to new advances, but for the most part they were hindered by slow policy developments and lack of stimulus from the federal centre [89].

Finally, Russia's membership of Nordic and Baltic Sea region organisations (CBSS, BASREC, EU Strategy for the Baltic Sea Region, and the Northern Dimension policy) increased the integration of Northwest Russia into the region around the Baltic Sea. This contrasts with other Russian regions (e.g. the Black Sea region or the Far East), where integration tendencies with Europe or other countries are largely absent, or even opposed by Russia [90]. For almost 40 years Russia has cooperated with Europe in the field of environment and energy, and Russian Northwest region has been a forerunner in that. These existing transnational networks, institutions and norms have a positive influence on the development of sustainable energy in Russia. However, the ongoing international crisis, especially between Russia and the EU, will test the resilience of established arrangements and it remains to be seen how the crisis affects the Russian (sustainable) energy sector.

\section{References}

[1] Russian Ministry of Natural Resources and Environment. Report of the Minister "On the state register and classification of hydrocarbon reserves" (July 12, 2013). Available from: http://www.mnr.gov.ru/upload/iblock/578/doklad_12 07 13.doc. Russian.

[2] IEA. World Energy Outlook 2013. Paris: OECD; 2013.

[3] Russian Ministry of Energy. Decree No. 162 "On amendments to the scheme for the location of electric power generating facilities using renewable energy sources in the Russian Federation" (April 19, 2012). Russian.

[4] Russian Government. Decree No. 1715-r on Approval of the "Energy Strategy of Russia for the period up to 2030" (Nov. 13, 2009). Russian. 
[5] Rosstat. Regions of Russia: Main characteristics of subjects of the Russian Federation. Statistical Handbook. Moscow: Russian Federal State Statistics Service; 2012. Russian.

[6] The Republic of Karelia official portal [Internet]. Petrozavodsk: The official portal; c19982014 [cited 2014 Aug 11]. Composition of Northwest Federal District; [about 1 screen]. Available from: http://gov.karelia.ru/gov/Maps/nw1_e.gif/. Russian.

[7] Rosstat. Regions of Russia: Socio-economic indicators. Statistical Handbook. Moscow: Russian Federal State Statistics Service; 2012. Russian.

[8] Rosstat. Forest sector of the regions of Northwestern Federal District of Russia. Vologda: Vologda Branch of Federal State Statistics Service (VologdaStat); 2010. Russian.

[9] Gerasimov Y, Karvinen S, Leinonen T. Atlas of the forest sector in Northwest Russia 2009. Joensuu: Joensuu Research Unit; 2009 Working Papers of the Finnish Forest Research Institute No.: 131.

[10] Gerasimov Y, Karjalainen T. Energy wood resources in Northwest Russia. Biomass and Bioenergy 2011;35:1655-62.

[11] Rosstat. Forest sector of the regions of Northwestern Federal District of Russia. Vologda: Vologda Branch of Federal State Statistical Service (VologdaStat); 2012. Russian.

[12] KSLA. The Swedish Forestry Model [Internet]. Stockholm: Royal Swedish Academy of Agriculture and Forestry; 2009 [cited 2014 Aug 12]. Available from: http://www.skogsstyrelsen.se/Global/myndigheten/Skog\%20och\%20miljo/ENGLISH/retrieve file.pdf.

[13] Rakitova O, Ovsyanko A, Sikkema R, Junginger M. Wood pellets production and trade in Russia, Belarus \& Ukraine. Pelletsatlas: market research report WP. 2009;6.

[14] Thek G, Obernberger I. The Pellet Handbook. The production and thermal utilisation of biomass pellets. London, Washington DC: Earthscan; 2010.

[15] Rakitova O, Kholodkov V. The pellet market and wood resources in the North-West of Russia. Final report. Baltic 21 Lighthouse project The Baltic Sea Bioenergy Promotion Project. SaintPetersburg: Biocenter; 2009 Nov. Report.

[16] Aleksandrova NB. Characteristics of Creation of the Wood Pellets Market in Russia. Journal of Siberian Federal University. Humanities \& Social Sciences. 2008;1(4):443-54.

[17] Cleandex. Cleantech in Russia 2010. Moscow: IAA Cleandex; 2010.

[18] Cocchi M, Nikolaisen L, Junginger M, Goh CS, Heinimö J, Bradley D, et al. Global Wood Pellet Industry Market and Trade Study. IEA Bioenergy Task 40 "Sustainable International Bioenergy Trade"; 2011.

[19] Gorbunov A. When sawdust is more expensive than oil. Expert [Internet]. 2012 Jun [cited 2014 Aug 12];25(808):[about 8 screens]. Available from: http://expert.ru/expert/2012/25/kogda-opilki-dorozhe-nefti. Russian.

[20] UNECE/FAO. Forest Products Annual Market Review 2010-2011. Geneva: UN; 2011.

[21] UNECE/FAO. Forest Products Annual Market Review 2011-2012. Geneva: UN; 2012.

[22] UNECE/FAO. Forest Products Annual Market Review 2012-2013. Geneva: UN; 2013.

[23] Sikkema R, Steiner M, Junginger M, Hiegl W, Hansen MT, Faaij A. The European wood pellet markets: current status and prospects for 2020. Biofuels, Bioprod Bioref. 2011;5(3):25078.

[24] Ovsyanko A. Wood bioenergy y in Russia: history and current trends. Lesnaya Rossiya 2008;4:4-7. Russian.

[25] Rakitova O. The development of the pellet production in Russia 2011 [Internet]. National Bioenergy Union/Bioenergy International Russia; 2011 [cited 2014 Aug 12]. Available from: http://www.eubionet.net/GetItem.asp?item=digistorefile;277233;1540\&params=open;gallery.

[26] Infobio. Nine countries - leaders in the procurement of wood pellets in Russia [Internet]. The Bioenergy International; 2014 [cited 2014 Aug 12]. Available from: http://www.infobio.ru/news/2659.html. Russian.

[27] Goh CS, Junginger M, Cocchi M, Marchal D, Thrän D, Hennig C, et al. Wood pellet market and trade: a global perspective. Biofuels, Bioprod Bioref. 2013;7(1):24-42.

[28] Infobio. Ratings for the 10 largest exporters of wood pellets [Internet]. The Bioenergy International; 2014 [cited 2014 Aug 12]. Available from: http://www.infobio.ru/news/2663.html. Russian. 
[29] Shafrannik JK, Bushuyev VV, Bezkukikh PP. The concept of development and use of small and non-conventional energy sources in the energy balance of Russia. Moscow: Mintopenergo; 1994. Russian.

[30] Pristupa AO, Mol APJ, Oosterveer PJM. Stagnating liquid biofuel developments in Russia: Present status and future perspectives. Energy Policy. 2010;38:3320-8.

[31] Bezrukikh PP. Report of the RES Committee. Ten years of fighting for the development of renewable energy in Russia [Internet]. IX International Conference "Renewable energy and small-scale power generation - 2012"; 2012 June 14 [cited 2014 Aug 12]. Available from: http://www.energystrategy.ru/ab ins/source/Bezrukih 14.06.12.doc. Russian.

[32] Mol AP. Environmental deinstitutionalization in Russia. Journal of Environmental Policy \& Planning. 2009;11(3):223-41.

[33] Belonna. Energy Ministry thinks how to increase the share of RES in the country to $4,5 \%$ in 2020 [Internet]. 2012 Oct [cited 2014 Aug 12]. Available from: http://bellona.ru/news/news 2012/1351688352.66. Russian.

[34] Russian Government. Decree No. 321 on Approval of the "State Programme on "Energy Efficiency and Energy Development" (April 15, 2014). Russian.

[35] Russian Government. Decree No. 1724-p on Approval of the "Principles of state policy in the use, protection and reproduction of forests in the Russian Federation for the period up to 2030" (Sep. 26, 2013). Russian.

[36] Russian Government. Decree No. 1853p-P8 on Approval of the "Integrated Programme of Biotechnology Development in the Russian Federation for the period up to 2020" (April 24, 2012). Russian.

[37] Boute A. A comparative analysis of the European and Russian support schemes for renewable energy: return on European experience for Russia. The Journal of World Energy Law \& Business. 2011;4:157-80.

[38] Ministry of Economic Development. List of Technology Platforms [Internet]. 2011 Oct 18 [cited 2014 Aug 12]. Available from: http://www.economy.gov.ru/wps/wcm/connect/economylib4/en/home/docs/doc20111018.

[39] Grama Y. The Analysis of Russian Oil and Gas Reserves. International Journal of Energy Economics and Policy. 2012;2(2):82-91.

[40] Gerasimov Y, Karjalainen T. Estimation of supply and delivery cost of energy wood from Northwest Russia. Working papers of the Finnish forest research institute; 2009.

[41] IEA. World Energy Outlook 2011. Paris: OECD; 2011.

[42] Nekrasov AS, Sinyak YV, Voronina SA, Semikashev VV. State-of-the-art of Russia's heat supply systems. Studies on Russian Economic Development. 2011;22(1):20-30.

[43] Sukhanov VS, Levin AB. Available bioenergy resources in the Russian forestry sector [Internet]. State Scientific Centre of the timber industry; 2012 [cited 2014 Aug 12]. Available from: $\quad$ http://gnclpkte.ru/wp-content/themes/zeecompany/images/Publications/Availableenergy-resources-in-the-Russian-timber-industry-complex.pdf. Russian.

[44] System Operator of the Unified Energy System of Russia. Press release: Electricity consumption in the UES of Russia in 2013 reduced by $0.6 \%$ compared with 2012 [Internet]. 2014 Jan 13 [cited 2014 Aug 12]. Available from: http://www.soups.ru/index.php?id=press release view\&no cache $=1 \&$ tx ttnews[tt news] $=5299$. Russian.

[45] Sukhanov Y, Seliverstov A, Gerasimov Y. Efficiency of Forest Chip Supply Systems in Northwest Russia. Advanced Materials Research. 2013;740:799-804.

[46] Hansen K, Ingerslev M, Felby C, Hirsmark J, Helynen S, Bruzgulis A, et al. Bioenergy in the Nordic-Baltic-NW Russian region-status, barriers and future. Nordic Council of Ministers, TemaNord 2006: 553. Copenhagen. 66 p. ISBN 92-893-1363-3; 2006.

[47] Petrov A, Lobovikov M. The Russian Federation Forest Sector: Outlook Study to 2030. FAO, Rome. 2012.

[48] Muran M, Flake L. Russian Federation biofuels annual. Biofuels sector update. Moscow: USDA Foreign Agricultural Service; 2013 July GAIN Report Number: RS1342.

[49] Infobio. Outcome of 2010 - the pellet production in Russia [Internet]. The Bioenergy International; 2011 [cited 2014 Aug 12]. Available from: http://www.infobio.ru/en/analytics/740.html. 
[50] Telnes E, Myachin K, Zhukova Y, Flagstad OA. Determination report: Wood waste to energy project at Sawmill-25 (Arkhangelsk) in Russian Federation. Det Norske Veritas Certification AS; 2007 June Report No.: 2007-9061. Available from: http://ji.unfccc.int/UserManagement/FileStorage/E3JSN6V1HCQ5KFWRX2IBTZGLMO8P7 0.

[51] Klenov G, Lukin, V. Determination report on JI project "Pellet Production from Sawmill Wastes at CJSC - Sawmill 25, Arkhangelsk, the Russian Federation". Bureau Veritas Certification; 2010 Sep. Report No.: RUSSIA/0067-2/2010v.1. Available from: http://ji.unfccc.int/UserManagement/FileStorage/KL1DO876FETB0CA3WV5NPG4R2MSXZ U.

[52] Titan Group [Internet]. Arkhangelsk: Group of companies Titan; c2006-2014 [cited 2014 Aug 12]. Bioenergy; [about 1 screen]. Available from: http://www.titangroup.ru/bioenergy. Russian.

[53] Russian Government. Decree No. 2446-r on Approval of the "State Programme of the Russian Federation for energy saving and energy efficiency for the period up to 2020" (Dec. 27, 2010). Russian.

[54] Audit Chamber of the Russian Federation. Monitoring of implementation of the "State Programme for energy saving and energy efficiency for the period up to 2020" [Internet]; 2013 [cited 2014 Aug 13]. Available from: http://audit.gov.ru/press center/news/269?sphrase id=82934. Russian.

[55] Korppoo A, Korobova N. Modernizing residential heating in Russia: End-use practices, legal developments, and future prospects. Energy Policy. 2012;42:213-20.

[56] Boute A. Modernizing the Russian District Heating Sector: Financing Energy Efficiency and Renewable Energy Investments under the New Federal Heat Law. Pace Environmental Law Review. 2012;29(3):746-810.

[57] Lamers P, Junginger M, Hamelinck C, Faaij A. Developments in international solid biofuel trade-An analysis of volumes, policies, and market factors. Renewable and Sustainable Energy Reviews. 2012;16(5):3176-99.

[58] AEBIOM. European Bioenergy Outlook 2013. Brussels: European Biomass Association; 2013 Dec. $120 \mathrm{p}$.

[59] European Commission. Directive 2009/28/EC of the European Parliament and of the Council of 23 April 2009 on the promotion of the use of energy from renewable sources and amending and subsequently repealing Directives 2001/77/EC and 2003/30. Official Journal of the European Union Belgium. 2009.

[60] European Commission. 2030 climate and energy goals for a competitive, secure and lowcarbon EU economy. European Commission Press release IP/14/54. 2014.

[61] UNECE/FAO. European Forest Sector Outlook Study II (EFSOS II) 2010-2030. Geneva: UN; 2011.

[62] Hønneland G. Borderland Russians: Identity, Narrative and International Relations. New York: Palgrave Macmillan; 2010.

[63] Leland SR, Hoel AH. Learning by doing: The Barents cooperation and development of regional collaboration in the north. In: Aalto P, Blakkisrud H, Smith H, editors. The New Northern Dimension of the European Neighbourhood. Brussels: CEPS Paperbacks; 2008. p. 36-53.

[64] IEA/OECD. Climate Change Capacity Building in Annex I EITs: Issues and Needs. Document prepared for the OECD/IEA/IETA Workshop National Systems for Flexible Mechanisms: Implementation Issues in Countries with Economies in Transition. Paris: OECD; 2002.

[65] IEA/OECD. Activities Implemented Jointly. Partnerships for Climate and Development. Paris: OECD; 1997

[66] Uzzell J, Lehmann M, Nestaas I, Telnes E, Lund T, Våge G. Multi-Project Verification of Swedish AIJ Projects. Verification Results and Documentation. Eskilstuna: Swedish National Energy Administration; 2001.

[67] Stern T. Monitoring of Development of Bio-energetics in Northwest Region of the Russian Federation: The Swedish-Russian Cooperation. Vestnik SGTU. 2004;4(5):118-23. Russian. 
[68] Swedish Energy Agency. Swedish Climate Activities in Eastern Europe. What are the results of Sweden's investments to reduce greenhouse gas emissions in other countries? Eskilstuna: Swedish Energy Agency; 2002.

[69] Anker M, Brunstad B. Foreign involvement in the Russian energy sector: Lessons learned and drivers of change for the Northern Dimension. In: Aalto P, Blakkisrud H, Smith H, editors. The New Northern Dimension of the European Neighbourhood. Brussels: CEPS Paperbacks; 2008. p. 164-79.

[70] Gerasimov Y, Senko S, Karjalainen T. Nordic Forest Energy Solutions in the Republic of Karelia. Forests. 2013;4(4):945-67.

[71] Lausala, T, Vuorio U. International Energy Efficiency Activities in North-West Russia. In: Lausala T, Valkonen L, editors. Proceedings of the Joint Energy Workshop for North West Russia; 1999 Oct 7-8; St. Petersburg, Russia. Copenhagen: Nordic Council of Ministers; 2000. p. 153-83.

[72] Øverland I, Kjærnet H. Russian Renewable Energy: The Potential for International Cooperation. Aldershot: Ashgate Publishing; 2009.

[73] Tynkkynen N. Experiences of environmental cooperation between the Nordic countries and Russia: Lessons learned and the way forward. In: Aalto P, Blakkisrud H, Smith H, editors. The New Northern Dimension of the European Neighbourhood. Brussels: CEPS Paperbacks; 2008. p. 71-90.

[74] Lausala T, Valkonen L, editors. Proceedings of the Joint Energy Workshop for North West Russia; 1999 Oct 7-8; St. Petersburg, Russia. Copenhagen: Nordic Council of Ministers; 2000.

[75] Christian K, Summa T. State of the Region Report 2014. The Top of Europe - Emerging from the Crisis, Adapting to a New Normal. Copenhagen: Baltic Development Forum; 2014.

[76] Aalto P, Blakkisrud H, Smith H, editors. The New Northern Dimension of the European Neighbourhood. Brussels: CEPS Paperbacks; 2008.

[77] IFC. Renewable Energy Policy in Russia: Waking the Green Giant. Washington DC: International Finance Corporation; 2011.

[78] IFC. Regional Renewable Energy Tariffs in Russia. Washington DC: International Finance Corporation; 2013.

[79] Boute A, Willems P. RUSTEC: Greening Europe's energy supply by developing Russia's renewable energy potential. Energy Policy. 2012;51:618-29.

[80] Lighthouse. Quick Scan of Wind, Solar Energy and Combined Heat and Power in the Russian Federation [Internet]. Lighthouse Russia B.V.; 2013 [cited 2014 Aug 12]. Available from: http://www.rvo.nl/sites/default/files/Final\%20report\%20Lighthouse $\% 20$ on $\% 20$ wind $\% 20 \% 20 \mathrm{~s}$ olar\%20energy\%20and\%20CHP\%20sectors\%20in\%20Russia.pdf.

[81] UNECE. UNECE weekly. Economic Commission for Europe [Internet]. 2010 Aug [cited 2014 Aug 12];384:[about 2 p.]. Available from: http://www.unece.org/fileadmin/DAM/highlights/unece weekly/weekly 2010/UNECE weekl y 2010-384.pdf.

[82] Mol APJ. Bounded Biofuels? Sustainability of Global Biogas Developments. Sociologia Ruralis. 2014;54(1):1-20.

[83] Pelkmans L, Goovaerts L, Goh CS, Junginger M, van Dam J, Stupak I, et al. The Role of Sustainability Requirements in International Bioenergy Markets. In: Junginger M, Goh CS, Faaij A, editors. International Bioenergy Trade: History, status \& outlook on securing sustainable bioenergy supply, demand and markets. Dordrecht: Springer; 2014. p. 125-49.

[84] Heinimö J, Junginger M. Production and trading of biomass for energy - An overview of the global status. Biomass and Bioenergy. 2009;33(9):1310-20.

[85] Gerasimov Y, Senko S, Karjalainen T. Prospects of forest road infrastructure development in northwest Russia with proven Nordic solutions. Scandinavian Journal of Forest Research. 2013;28(8):758-74.

[86] Malikova G. Pellet industry: Mistakes and prospects. Derevo.ru [Internet]. 2012 [cited 2014 Aug 12];1:[about 7 p.]. Available http://www.derewo.ru/derewo jornal_pdf/2012/bio_oshibki.pdf. Russian.

[87] Rakitova O. The Vyborgskaya Cellulose 1 Mton pellet plant: "We are on schedule". Bioenergy International. 2010;45(4):15. 
[88] Arbitration Court of Appeals. The claim of the public company "Petersburg Energy Retail Company" to the limited liability company "Vyborg Forest Corporation" [Internet]. Arbitration Court of Appeals No.13; 2013 [cited 2014 Aug 12]. Available from: http://13aas.arbitr.ru/cases/cdoc?docnd=784388671\&nd=784058521\&prefix $=\&$ numdeal $=\& y e$ ardeal $=\&$ fld $12=\&$ fld $14=\&$ fld $16=\&$ fld $140=$ \&pagedoc $=1$. Russian .

[89] Boute A. Renewable Energy Federalism in Russia: Regions as New Actors for the Promotion of Clean Energy. Journal of Environmental Law. 2013;25(2):261-91.

[90] Nilsson N. EU and Russia in the Black Sea Region: Increasingly Competing Interests? Romanian Journal of European Affairs. 2008;8(2):25-39. 